\title{
Assessment of Anti-Fungal Activity of Annona senegalensis Plant Parts on Malassezia globosa
}

Ochieng O Anthony ${ }^{1 *}$, Omar H Said ${ }^{1}$, Ibrahim Hamisi ${ }^{1}$, Matake A Matake ${ }^{1}$, Ochieng J Odalo ${ }^{2}$, Pakia Mohamed ${ }^{3}$, Oyoo O Titus ${ }^{4}$

${ }^{1}$ Department of Science, Sumait University, Zanzibar Town, Tanzania

${ }^{2}$ Department of Pure and Applied Sciences, Technical University of Mombasa, Tom Mboya Street, Mombasa, Kenya

${ }^{3}$ Department of Botany, Pwani University, Kilifi, Kenya

${ }^{4}$ Kenya Bureau of Standards

*Corresponding author: Ochieng O Anthony, Department of Science, Sumait University, Zanzibar Town, Tanzania, Tel: +254720852957; E-mail: d_norbatus@yahoo.com

Received: August 18, 2017; Accepted: August 24, 2017; Published: September 01, 2017

Copyright: (C) 2017 Anthony O, et al. This is an open-access article distributed under the terms of the Creative Commons Attribution License, which permits unrestricted use, distribution, and reproduction in any medium, provided the original author and source are credited.

\begin{abstract}
The pondered parts (mixture of fresh leaves, twigs \& soft stem barks and soft root extract) of Annona senegalensis plant have been used as ethno-medicine for treating patients suffering from tinea versicolor. The antifungal activities of dichloromethane and methanol (1:1), methanol, water, acetone, ethanol, ether and chloroform extracts of Annona senegalensis (Annonaceae) parts were investigated and primarily assessed against cultured Malassezia globosa fungus isolated from willing tinea versicolor patients. The efficacy of the extracts was studied and determined by applying different extracts concentrations on agar slants carrying the fungus in an incubator. The susceptibility of tested fungus on the extracts was determined by measuring the diameter of inhibition zones formed around the disc. The highest anti-fungal activity was observed in methanol fresh leaf extract gave an inhibition zone of $9.667 \pm 0.557 \mathrm{~mm}$ while methanol twigs and soft bark extract gave lowest inhibition zone of $4.333 \pm 0.5773 \mathrm{~mm}$ compare with gentamycin which gave an inhibition zone of $15 \mathrm{~mm}$ after 24 hours. Thus combination of the mixtures confirms the antifungal synergistic interaction against the Malassezia globosa fungus. The water, acetone, ethanol, ether and chloroform plant extracts showed no inhibition zones hence proved ineffective at the evaluated concentrations. The preliminary phytochemical screening of the plant parts also indicated the presence of the relevant phytochemical constituents, thus supports its medicinal values.
\end{abstract}

Keywords: Annona senegalensis extract; Anti-fungal activity; Ethnomedicine; Malassezia globosa; Tinea versicolor, Phytochemical; Inhibition Zone

\section{Introduction}

Treatment of fungal infections and diseases related to fungal infections is posing a real challenge to medical practitioners mainly due to resistance caused by overuse and uprising side-effects after use of antifungal medications or mythical beliefs. Plants commonly used in traditional medicines are assumed to be free from adverse effects due to their long usage in treatment of diseases according to knowledge accumulated over centuries despite recent scientific finds has shown that many plants used as food or in ethnomedicine are potentially toxic, mutagenic and carcinogenic [1,2]. As global scenario is now changing towards the use of nontoxic plants products having traditional medicinal use, the development of modern drugs from medicinal plants should be emphasized for the control of various infections. It has already been estimated that 122 drugs from 94 plants species have been through ethnobotanical leads [3]. Medicinal plants have become important for treatment of different disease conditions, such as malaria, diabetes, anemia, etc., $[4,5]$ but the potential of higher plants as source of new drugs is still unexplored. Systematic screening of them may result in the discovery of novel effective compounds [6]. It is likely that plants will continue to be a valuable source of new molecules which may, after possible chemical manipulation, provide new and improved drugs [7].
Due to financial constraints, easy inaccessibility and limited availability of affordable conventional pharmaceutical medicines in third world regions, a high percentage of African population are using complementary and alternative medicine as the only treatment $[8,9]$ and this justifies the frequent use of medicinal Annona senegalensis plant in many countries which it grows wildly.

Tinea Versicolor (also known as dermatomycosis furfuracea, pityriasis versicolor, or Tinea flava) is one of the most common skin fungal infections found in East African regions particularly the coastal regions or in hot and humid climates or sometimes on those who sweat profusely. This ailment is caused by the Melassezia globosa fungus which gives the infected tissue on the skin some pigment change (hypopigmentation). The treatment of this skin fungal infection has been a painstaking process since it takes time to heal and do recur upon treatment $[10,11]$. Some experiences skin irritation upon applying orally the available antifungal ointments while others believes that this infection is due to bewitchment or going against the taboos thus prefers using Annona senegalensis plant tissues as the best alternative treatment rather than pharmaceutically manufactured medicines.

In managing the Tinea versicolor disease, the traditional healers often administer the medicinal preparation by pondering the fresh soft root backs and fresh leaves into a paste and apply (rubbing) the mashed product over the infected tissue areas of the skin.

The plant Annona Senegalensis (Annonaceae), Mtopetope in Swahil language, Giishta in Amharik, grows wildly in Zanzibar. It is a shrub or 
small tree 2-6 $\mathrm{m}$ tall but may reach $11 \mathrm{~m}$ under favourable conditions; bark smooth to roughish, silvery grey or grey-brown, with leaf scars and roughly circular flakes exposing paler patches of under bark. Leaves alternate, simple, oblong, ovate or elliptic, 6-18.5 $\times 2.5-11.5 \mathrm{~cm}$, green to bluish-green, almost without hairs on top, but often with brownish hairs on underside, net veining green to reddish on both surfaces; apex rounded or slightly notched; base square to slightly lobed; margin entire; petiole short, $0.5-2.5 \mathrm{~cm}$, thickset. Flowers up to $3 \mathrm{~cm}$ in diameter, on stalks $2 \mathrm{~cm}$ long, solitary or in groups of $2-4$, arising above the leaf axils; 6 fleshy cream to yellow petals in 2 whorls, greenish outside, creamy or crimson, $0.8-1.5 \times 0.9-1.1 \mathrm{~cm}$, glabrous or minutely papillose within; inner whorl of the petals curving over the stamens and ovary; sepals ovate, 3 in number, free, smaller than the petals, 3-4 × 4-5 mm; stamens 1.7-2.5 $\mathrm{mm}$ long.

The plant is reputed to be of great medicinal value and is used in native medicine [12]. It have been used against snake venom [13,14], for chest pain, coughs, anemia, urinary tract infection $[15,16]$, venereal diseases [17,18], anthritis and rheumatism [19], diarrohea and dysentery [20-22], against malaria [23], head and body ache [24,25] anti- bacterial [26], against leishmaniasis [27], against typanasomiasis [28], eyelid swelling [29] Antiprotozoan [30], antitumor agent [31,32], molluscisidal [33] antiulcer/antacid, smooth muscle relaxant [34], anthelmintic activity [35] and also for cancer treatment [17,36]. A lot of scientific studies have been done and reported concerning its medicinal values but none so far on skin ailments caused by the fungus Melassezia globosa.

In this study, (done in Zanzibar-Unguja Island), we make the effort to identify the phytochemical constituents of the extracts, determine inhibitory zone of intrinsic antifungal activity of the plant extracts, promote and upgrade the ethno-medicinal use of Annona senegalensis in managing the Melassezia globosa fungus causing the skin infection (Tinea versicolor).

\section{Materials and Methods}

\section{Collection and identification of the plant materials}

The samples of Annona senegalensis (Annonaceae) plant was collected by Ibrahim and Mataka (Science department, Sumait University-Tanzania) from within the Sumait University environs, Zanzibar (Unguja Island) and authenticated by Dr. Pakia Mohamed (Botany department, Pwani University, Kenya).

\section{Preparation of Annona senegalensis aqueous extracts}

After collection, the fresh leaves and twigs-soft barks were dried in a shade for five days while the soft root tissues were washed with distilled water and dried in the shade for two weeks. The fresh leaves and twigs-soft barks were then mashed differently (approximately $1 \mathrm{~kg}$ each) while the roots were pulverized to fine powder approximately $780 \mathrm{~g}$. Both were divided into seven different $500 \mathrm{ml}$ beakers containing different solvents i.e., water, acetone, ethanol, ether, chloroform, methanol, dichloromethane and methanol 1:1 mixture, covered and left to stand at room temperature, for six days with continuous monitoring and occasionally shaken. The liquid extracts obtained were subjected to Rotary evaporator and subsequently concentrated under reduced pressure (in vacuum at $40^{\circ} \mathrm{C}$ ) and evaporated to dryness then stored at $4^{0} \mathrm{C}$ in air tight bottle.

\section{Culturing of Malassezia globosa Fungus}

20 petri dishes and watch glasses were cleaned and disinfected in the autoclave for two hours. 32.5 gms of sabourand dextrose agar was dissolved in $500 \mathrm{ml}$ of distilled water, placed in the autoclave for 15 minutes at $121^{\circ} \mathrm{C}$ and at $15 \mathrm{lbs}$ pressures. The agar solution (yellowish) was then removed from the autoclave poured into 15 petri dishes and smeared with the Melassezia globosa fungus extracted from identified willing Tinea versicolor patients using a sterilized cotton wool. The two petri dishes were marked and put into a separate incubator to allow further growth of fungus for 48 hours.

After the 48 hours, the cultured fungus was collected and portion of the fungus were sub cultured into other five sterilized petri dishes containing the agar solution for two days in the incubator at $37^{\circ} \mathrm{C}$ to obtain pure culture (whitish colonies).

The sub cultured fungus was collected and introduced into seven sterilized petri dishes which contained sabourand dextrose agar.

\section{Fungus inoculation and disc-diffusion method [41]}

Antimicrobial susceptibility test: $3.8 \mathrm{~g}$ of Muller H. Agar was added to $100 \mathrm{ml}$ distilled water and autoclaved at $121^{\circ} \mathrm{C}$ for 15 minutes at 15 lbs and poured in sterile petri plates to a uniform thickness of approximately $4 \mathrm{~mm}$ and the agar allowed to set at ambient temperatures and used.

Sterile empty filter paper discs (Bio-analyze) of $6 \mathrm{~mm}$ were impregnated with $50 \mu \mathrm{l}$ of plant extracts and they were then aseptically placed over the standard media (Muller Hinton Agar) equidistant from each other with the test organism. The plates were then incubated at $37^{\circ} \mathrm{C}$ for 24 hours and monitored.

Determination of Zone of Inhibition: The antifungal activity was evaluated by measuring zone inhibition using Hi Media zone scale. The diameter of the inhibition zones was measured in $\mathrm{mm}$. Standard disc of gentamycin $(10 \mu \mathrm{g} / \mathrm{disc})$ was used as a positive control and methanol was used as a negative control.

\section{Phytochemical Screening of Extracts of Annona senegalensis}

The phytochemical studies were done to ascertain the chemical components which may be responsible for the medicinal values and health benefits. The screening of the concentrates was qualitatively done according to the established protocols [37-41]. Stock solution of each concentrate $10 \mathrm{mg}$ extract/ $\mathrm{ml}$ of distilled water was also prepared, besides their dried powder, and used for the qualitative identification of the phytochemical constituents.

Test for alkaloids: Approximately $1 \mathrm{~g}$ of powdered sample of each specimen added $10 \mathrm{ml}$ of $\mathrm{HCl}$ separately boiled on a water bath then filtered to obtain a clear filtrate. Added 6 drops of Mayor's reagents to 2 $\mathrm{ml}$ of filtrate. A creamish or pale yellow precipitate indicates the presence of alkaloids.

Test for amino acids: Approximately $1 \mathrm{~g}$ or equivalent of each specimen sample extracted added $10 \mathrm{ml}$ of distilled water, shaken to dissolve, added few drops of ninhydrin reagent, appearance of purple color confirms the presence of amino acids.

Test for cardiac glycosides: $5 \mathrm{ml}$ of each extract was treated with $2 \mathrm{ml}$ of glacial acetic acid containing one drop of ferric chloride solution. This was underplayed with $1 \mathrm{ml}$ of concentrated sulphuric acid. A brown ring at the interface indicated the deoxysugar characteristics of 
Page 3 of 5

cardenolides. A violet ring may appear below the ring while in the acetic acid layer, a greenish ring may be formed.

Test for carotenoids: Approximately $1 \mathrm{~g}$ or equivalent of each specimen sample was extracted with $10 \mathrm{ml}$ of chloroform in a test tube with vigorous shaking. The resulting mixture was filtered and then added $85 \%$ sulphuric acid. A blue coloration at the interface confirms the presence of carotenoids.

Test for flavonoids: Approximately 1g of the dried powdered extract was boiled with $10 \mathrm{ml}$ of distilled water for 5 minutes and filtered when hot then added few drops of $20 \% \mathrm{NaOH}$ solution to $1 \mathrm{ml}$ of the filtrate. A change to yellow colouration that on addition of acid and finally to colourless solution depicted the presence of flavonoids.

Test for reducing sugars: Approximately $1 \mathrm{~g}$ of each specimen placed in a test tube added $10 \mathrm{ml}$ distilled water and boiled for 5 minutes. The mixture was filtered while hot and the cooled filtrate made alkaline to litmus paper with $20 \% \mathrm{NaOH}$ solution. The resulting solution was boiled with equal volume of Benedict's qualitative solution on a water bath. The formation of a brick red precipitate depicts the presence of reducing compounds.

Test for saponins: $1 \mathrm{~g}$ of each dried powder was separately boiled with $10 \mathrm{ml}$ of distilled water in a bottle bath for 10 minutes. The mixture was filtered while hot then allowed to cool. $2.5 \mathrm{ml}$ of the filtrate was diluted to $10 \mathrm{ml}$ with distilled water and shaken vigorously for 2 minutes, frothing indicates the presence of saponins in the filtrate.

Test for tannins: Approximately $1 \mathrm{ml}$ of the extract or its equivalent weight in grams treated with few drops of $1 \%$ ferric chloride and observed for brownish green or a blue-black coloration to confirm the presence of tannins.

Test for phlobatanins: Approximately $1 \mathrm{ml}$ of aqueous extracts or its equivalent weight, boiled with $1 \%$ aqueous hydrochloric acid to give deposition of red precipitate confirms the presence of phlobatanins.

\section{Results}

\section{Bio activity assay}

After 24 hours of incubation, the inhibition zones of the extracts were measured and recorded as shown at the Table 1. The zones of inhibition were measured across the diameter and averaged (Figure 1).

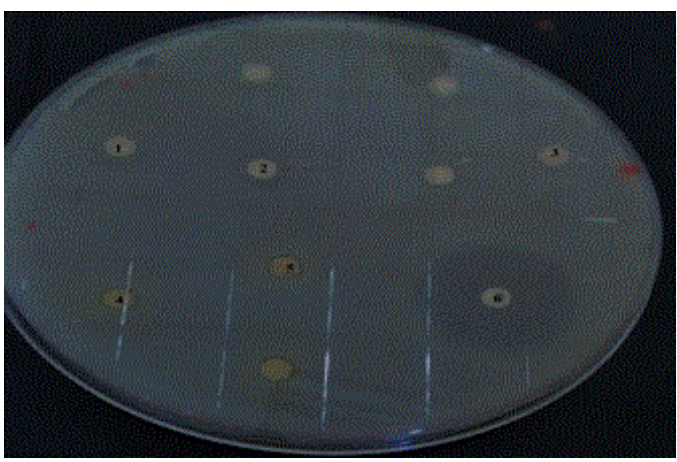

Figure 1: Inhibition zones of Annona senegalensis extracts. 1 and 2 including the unmarked disc in the same quadrangle-Leaf extract, 3 including the two unmarked in the same quadrangle-Twigs and Soft bark extract, 4 and 5 including the unmarked yellowish disc-Root extract, 6-Gentamycin.

\section{Anti-fungal activity test based on Disc diffusion assay}

\begin{tabular}{|l|l|l|l|}
\hline Fresh Leaves extract & $\begin{array}{l}\text { Twigs and soft stem bark } \\
\text { extract }\end{array}$ & Soft Root extract & Gentamycin \\
\hline $9.667 \pm 0.5773$ & $4.333 \pm 0.5773$ & $6.7 \pm 0.6083$ & 15 \\
\hline
\end{tabular}

Table 1: Zones of inhibition (in $\mathrm{mm}$ ) for different methanol extracts of Annona senegalensis plant parts.

The water, acetone, ethanol, ether and chloroform extracts showed no inhibition zones hence proved ineffective at the evaluated concentrations.

\section{Phytochemical analysis}

Analysis on the plant extracts revealed the presence of phytochemical constituents as shown in Table 2 below.

\begin{tabular}{|l|l|l|l|}
\hline Phytochemicals & Fresh leaves & Twigs and soft stem barks & Soft roots \\
\hline Flavonoids & ++ & + & + \\
\hline Cardiac glycosides & + & + & ++ \\
\hline Alkaloids & ++ & + & ++ \\
\hline Tannins & ++ & + & + \\
\hline Phlobatanins & ++ & - & + \\
\hline
\end{tabular}

\begin{tabular}{|l|l|l|l|}
\hline Saponins & + & + & + \\
\hline Reducing Sugars & + & + & ++ \\
\hline Amino acids & + & + & + \\
\hline Carotenoids & ++ & + & + \\
\hline $\begin{array}{l}+ \text { indicates presence of phytoconstituent; ++ more concentrated amounts; - } \\
\text { indicates absence of phytoconstituent }\end{array}$
\end{tabular}

Table 2: Result of Phytochemical screening of methanol extracts.

\section{Discussion}

This study has revealed that highest inhibition zone is experienced in the fresh leaf extract with least being the twig \& soft bark extract. The fresh leaf extract also has the highest concentration of phytoconstituents thus supporting its medicinal efficacy incomparable 
Page 4 of 5

to other parts. Thus the confirmation of ethnomedicinal antifungal activity of the Annona senegalense plant parts can be attributed to several bioactive compounds found in the methanol extract of the plants parts since the other extracts showed no inhibitions zones against the evaluated fungal concentrations. Combining these different plant parts extract can lead to synergistic treatment for the infectious Melassezia globosa fungus. Moreover, persistence and recurring of the skin fungal infections (tinea versicolor) after continuous treatments has been a painstaking issue with most medics and this has led to most patients indiscriminately use antifungal medicinal product hence causing alarming resistance among microorganism [37,38]. Thus, combining plants extracts can give an alternative approach that might help to tackle infections caused by resistant pathogens [39] with the help of modern bioassay techniques [40,41]. Annona senegalensis has also been found to posses anti-yeast and antibacterial activities [42].

The existence of phytoconstituents alkaloids, cardiac glycosides, carotenoids, lavonoids, tannins, phlobatanin and saponins are the antifungal principles of plants and has also been identi ied in annona senegalensis [43,44]. More recent studies also revealed that the methanol extract of the root bark has analgesic and anti-inflamatory activities [45], proteins, amino acids and antraquinones [14,19,46], sterol, terpenoids, acetogenins [48-51] diterpenes [52], wax and alkaloids [53,54]. The leaf extracts contains anthraquinones and cardiac glycosides. These active constituents can be used to search for bioactive lead compounds that could be used in the partial synthesis of more useful drugs [55-56].

Diterpenes, wax and alkoloids. The leaf extracts also contains antraquinones which is known for stimulating laxative effects. These active constituents can be used to search for bioactive lead compounds that could be used in the partial synthesis of more useful drugs Moreover, the brine shrimp lethality test has also been done to test the activity of the methanol extract and to estimate its toxicity against zoological systems yielding positive results. LC50 was established to be $232.7 \mu \mathrm{g} / \mathrm{ml}[57,58]$ thus con irming its safeness. In addition, Annona senegalensis has been tested for cytotoxicity against human A2780 ovarian cancer cells and found to be low with IC50 at $28.8 \mu \mathrm{g} / \mathrm{ml}$ [59-61].

Thus, this study confirms that these plant extracts can offer a recommendable antifungal medicine particularly against the stubborn Melassezia globosa fungus.

Still more needs to be done in determining the safety profile of the plant in the medicinal field. Thus, protection of the plant is mandatory and need to be commercialized.

\section{Conclusion and Recommendation}

The extracts of annona senegalensis when used as medicinal plant, could be useful for the growth inhibition of the malessezia globosa fungus. Blending the antifungal extracts from the plant, at evaluated concentrations, in a soap preparation would give a suitable herbal antifungal soap thus making it easy to use and apply and also can be used as a preventive measure for fungal infection in these regions with continuous bathing using the herbal soap. More studies needs to be done in characterizing this bioactive antifungal compound and doing more comparative studies with other available antifungal drugs to establish its efficacy.

\section{Acknowledgement}

Thanks goes to Dr. Odalo J. Ochieng for extra consultations, chemical analyzes, organization and criticisms of the manuscript, Omar H. Said for microbial assay, the local traditional herbalists, local Mnazi hospital, Dr. Hassan M. Mussa (Medical Practitioner) and willing patients. This study was partially financed by SUMAIT University.

\section{References}

1. Adesogan EF, Durodola JI (1976) Antitumor and antibiotic principles of Annona senegalensis. Phytochemistry 15: 1311-1312.

2. Adzu B, Amos S, Adamu M, Gamaniel K (2003) Anti-nociceptive and anti-inflammatory effects of the methanol extract of Annona senegalensis rootbark. J Natu Rem 3: 63-67.

3. Adzu B, Abubakar BMS, Izebec KS, Gamaniela DDKA (2005) Effect of Annona senegalensis rootbark extracts on Naja nigricotlis venom in rats. Journals of Ethnopharm 96: 507-513.

4. Ajaiyeoba E, Falade M, Ogbole O, Okpako L, Akinboye A ( 2006) In vivo antimalarial and cytotoxic properties of Annona senegalesis extracts (shirt communication). Afr J trad CAM 3: 137-141.

5. Akendengue B, Ngou-Milamg E, Laurens A, Hocquemiller R (1999) Recent advances in the fight against leishmaniasis with natural products. Parasites 6: 39 .

6. Alawa CBI, AdamuAM, Gefu JO, Ajanusi O, Abdu PA, et al. (2003). In vitro screening of two Nigerian medicinal plants (Vernonia amygdalina) and (Anonna senegalensis) for anthelmintic activity. Veterinary Parasitology 113: 73-81.

7. Arnold HJ, Gulumian M (1984) Pharmacopoeia of traditional medicine in Venda. Journal of Ethnopharmacology 12: 35-74.

8. Atawodi SE, Ameh DA, IbrahimS, Andrew JN, Nzelibe HC, et al. (2003) Indigenous knowledge system for treatment of typanasomiasis in Kaduna State of Nigeria. Journal of Ethnopharmacology 79: 279-282.

9. Audu J (1989) Medicinal herbs and their uses in Bauchi State. The Nigerian Field 54: 157-168.

10. Bakarnga-Via I, Yande HK, Kouipou RM, Kanko MIM, Arc-En-Ce JM, et al. (2016) Effects of combined extracts from different plants parts of annona senegalensis on antibacterial and antifungal activities. International Journal of Pharmacognosy and Phytochemical Research 8: $162-166$.

11. Balansard G, Timon-David P (1985) Pharmaceuticals containing quinine or cinchona bark extracts and tannins. Patent-Frodemande 2: 550.

12. Bamba PD, Abalansard G, Maillard C, Demenil G, Gayte-Sorbier A (1984) Characterization of amino acids in the stem bark of Annona senegalensis Pers. Plante Medicinales Phytotherapie 18: 36-45.

13. Bauer A. W., Kirby W. M., Cherris J. C., and Truck M., (1966). Antibiotic susceptibility testing by a standardized single disk method. The American Journal of Clinical Pathology. 1966; 45, No 4, 493-496.

14. Bhatt R.B., Eterjere E.O., Oladipo B.I., (1990). Ethnobotanical studies from central Nigeria. Economic Botanical 44, 382-390.

15. Burkill HM (1985) The Useful Plants of West Africa. Royal Botanical Gardens, Kew, pp: 103-105.

16. Chhabra SC, Mahunnah RLA, Mshiu EN (1987) Plants used in traditional medicine in Eastern Tanzania. 1. Pteridopyhtes and Angiosperms (Aquanthaceae to Canelliceae). Journal of Ethnopharmacology 21: 253-277.

17. Ciulei I (1982) Methodology for analysis of vegetable drugs. Practical manuals on industrial utilization of medicinal and aromatic plants. Edited by the Ministry of chemicals Industry, Bucharest p: 73.

18. Dalziel JM (1937) The useful plants of West Tropical Africa. Crown overseas agents for the colonies, London. Pp: 2-3.

19. De SãFerrira I. C. F., Ferrão Vargas V. M., (1999). Mutagenicity of medicinal plant extracts in salmonella/microsome assay. Phytother. Res. $13,397-400$ 
20. Durodola JI (1975) Viability and transplanability of developed tumour cells treated in vitro with antitumour agent C/M2 isolated from herbal cancer remedy of Annona senegalensis. Planta Medica 28: 359.

21. Ekpendu TOE, Obande OD, Anyogo PO, Attah AD (1998) Nigerian ethnomedicine and medicinal plant flora-the Benue experience part 1. Journal of Pharmaceutical Research and Development 3: 37-46.

22. Ekundayo O, Oguntimein B (1986) Composition of the essential oils of Annona senegalensis Var. senegalensis. Planta Medica 52: 202-204.

23. El- Mahmood AA, Ogbonnia M, Rajii M ( 2010) The antibacterial activity of Azadarichata indica (neem) seeds extracts against bacterial pathogens associated with eye and ear infections. J Med Plant Res 4: 14.

24. Eshiet ITU, Akisanya A, Taylar DAH (1971) Diterpenes from Annona senegalensis. Phytochem 10: 3294

25. Fatope MO, Audu OT, Takada Y, Zeng I, Shi G, et al. (1996) Bioactive entkaurene diterpenonids from Annona senegalensis. J Natu Prod 59: 301-303.

26. Fatope MO, Ibrahim H, Takeda Y (1993) Screening of higher plants reputed as pesticides using the brine shrimp lethality assay. International Journal of Pharmacognosy 31: 250-254.

27. Frabricant DS, Farnsworth NR (2001) The value of plants used in traditional medicine for drug discovery. Environ Health Persp 109:: 69-77.

28. Gbeassor M, Koumaglo HK, Awang DVC, Durst J, Mackinnon S, et al. (1996) Development of ethical phytomedicines for Togo, West Africa. In: Chemistry, Biological and Pharmacological Properties of African Medicinal Plants. University of Zimbabwe Publications pp: 336.

29. Graham JG, Quinn ML, Fabricant DS, Farnsworth NR (2000) Plants used against cancer- an extension of the work of Jonathan Hartwell. Journal of Ethnopharmacology 73: 343-377.

30. Harbone A.J., (1998). Phytochemical methods A guide to modern techniques of plant analysis 3rd edition.

31. Igweii AG, Onabanjo AO (1989) Chemotherapeutic effects of Annona senegalensis in Trypanasoma brucei brucei. Annals of Tropical Medicine and Parasitology 83, 527-534.

32. Klaus V, Adala HS (1994) Traditional herbal eye medicine in Kenya. World Health Forum 15: 138-143.

33. Kudi AC, Myint SH (1999) Antiviral activity of some Nigerian medicinal plant extracts. Journal of Ethnopharmacology 68: 289-294.

34. Levy SB (2002) The antibiotic paradox. How the misuse of antibiotics destroys their curative powers. Cambridge MA. Perseus Publishing.

35. Langason RBF, Akunyili DN, Akubue PI (1994) A Preliminary study of the gastrointestinal effects of some Nigerian medicinal plants.

36. McLaughlin JK, Chang CJ, Smith DL (1991) "Bench top" bioassays for the discovery of bioactive natural products; an update. In: Rahman, A.U. (Ed.), Studies in Natural Product Chemistry. Elsevier, Amsterdam, pp: 383-409.

37. Meyer BN, Ferrigni NR, Putnam JE, Jacobsen L, Nichols DE, et al (1982) Brine Shrimp: a convenient in general bioassay for active plant constituent. Planta Medica 45: 31-34.

38. Midiwo JO, Clough JM (2009) Natural products from Biodiversity and their use in treatment of neglected diseases.

39. Millogo A, Ratsimbazafy V, Nubukpo P, Barro S, Zongo I, et al. (2004) Epilepsy and traditional medicine in Bobo-Dioulasso (Burkina Faso). Acta Neurol Scand 109: 250.

40. Morishita N, Sei Y, Sugita T (2006) Molecular analysis of Malassezia microflora from patients with pityriasis versicolor. Mycopathologia 16: 161-165.

41. Muanza DN, Kim BW, Euler KL, Williams L (1994) Antibacterial and antifungal activities of nine medicinal plants from Zaire. International Journal of Pharmacognosy 32: 337-345.
42. Nkunya MHH, Gessler MC, Mwasunmbi LB, Heinrich M, Tanner M (1994) Screening Tanzania medicinal plants for antimalarial activity. Acta Trop 56: 65-77.

43. Ogbonnia SO, Enwuru NV, Onyemenen EU, Oyedle GA, et al. (2008) Phytochemical evaluation and antibacterial profile of Treculi Africana Decne bark ex-tract on gastrointestinal bacterial pathogens. Afr J Biotechnol 7: 1385-1389.

44. Ostrosky-Zeichner L., Casadevall A., Galgiani J.N., Odds F.C., Rex J.N., (2010).An insight into the antifungal pipeline: selected new molecules and beyond

45. Pfaller M.A., Diekema D.J., (2007). Epidemiology of invasive candidiasis: a persistent public health problem. Clin. Microbiol. Rev., Vol 20, pp. 133-163

46. Philipov S, Kande KM, Machev K (1995) Alkaloids of Annona senegalensis. Fitoterapia 66: 275-276.

47. Prescott H, Klein JO (2002) Microbiology 6th edition Macgraw Hill Publishers, USA pp: 808-823.

48. Preux PM, Druet-Cabanac M (2005) Epidemiology and aetiology of epilepsy in sub-Saharan Africa. Lancet Neurol 4: 21-31.

49. Rizzini CT, Mors WB, Pereira NA (1988) Plantas brasileiras tidas como ativas peconhas animais, especialmente venenos de cobras. Review Brasil Farmaceutico 69: 82-86.

50. Rupprecht JK, Hui YH, McLaughlin JL (1990) Annonaceous acetogenins. Journal of Natural products 53: 237-278.

51. Sahpaz S, Gonzalez MC, Hocquemiller R, Zafra-Polo MC, Cortes D (1996) Annosenegalin and Annogalene: two cytotoxic monotetrahydrofuran acetogenins from Annona senegalensis and Annona cherimolia. Phytochemistry 42: 106-107.

52. Schimmer O, Kruger A, Paulini H, Haefele F (1994) An evaluation of 55 commercial plant extracts in the Ames mutagenicity test. Pharmazie pp: 448-451.

53. Selvanayahgam ZE, Gnanevendhan SG, Balakrishna K (1994) Anti-snake venom botanicals from ethnomedicine. Journal of Herbs, Spices and Medicinal Plants 2: 45-100.

54. Shah NS, Richardson J, Moodley P, Moodley S, Babaria P, et al. (2011) Increasing drug resistance in extensively drug-resistant tuberculosis, South Africa. Emerg Infect Dis 17: 510-513.

55. Sofowora EA, Adewunmi CO (1980) Preliminary screening of some plant extracts for molluscidal activity. Planta Medica 39: 57-65.

56. Sofowora, Evans, Trease, Harborne (2012) www.ccsenet.org/ijb. International Journal of Biology 4: 66.

57. Sofowora EA (1993) Medicinal plants and traditional medicinal in Africa 2nd edition, 174: 195- 198.

58. Tomoko N, Takashi A, Hiromu T, Yuka I, Hiroko M, et al. (2002) Antibacterial Activity of Extracts Prepared from Tropical and Subtropical Plants on Methicillin-Resistant Staphylococcusaureus, J Health Sci 48: 273-276

59. Trease GK, Evans WC, Trease, Evans (1989) Pharmacognosy. A physical guide to herbal medicine, 13th Edition,Tindall ,London, p: 912.

60. Van Vuuren S, Viljoen (2011) A Plant-based antimicrobial studiesMethods and approaches to study the interaction between natural products. Plant Medica 77: 1168- 1182.

61. You M, Wickramaratne DBM, Silva GL, Chai H, Chagwedera TE, et al. (1995) (-)-Roemerine, an aporphine alkaloid from Annona senegalensis that reverses the multi-drug resistance phenotype with culture cells. J Natu Prod 58: 598-604. 